\title{
Agroforestry systems provide firewood for livelihood improvement in Guatemala
}

Nicole SiBeLET ${ }^{1,2,3}$

Karla E. PosAdA ${ }^{3}$

Isabel A. GutiÉRREZ-Montes ${ }^{3}$

${ }^{1}$ CIRAD

UMR INNOVATION

34398 Montpellier

France

2 INNOVATION

Univ Montpellier, CIRAD, INRA

Montpellier SupAgro

Montpellier

France

${ }^{3}$ CATIE

7170 Turrialba

30501 Turrialba

Costa Rica

\section{Auteur correspondant /}

Corresponding author:

Nicole SIBELET -

sibelet@cirad.fr

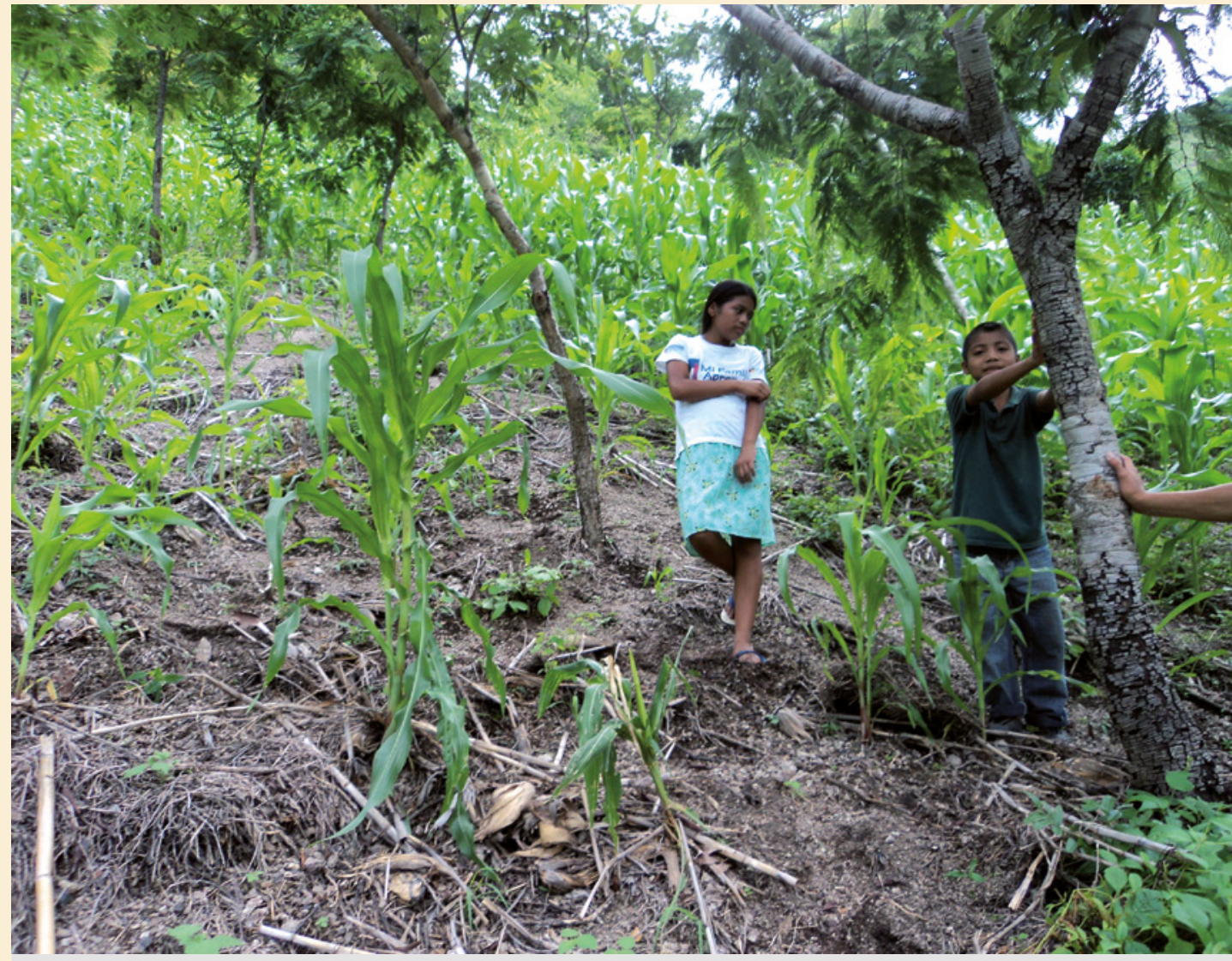

Photo 1.

Children from the village of Canapará Abajo in Jocotán, showing the trees in their corn crop.

Photo K. Posada.

Doi : 10.19182/bft2019.340.a31692 - Droit d'auteur (c) 2019, Bois et Forêts des Tropiques @ Cirad - Date de soumission : 4 octobre 2018 ; date d'acceptation : 11 janvier 2019 ; date de publication : $1^{\text {er }}$ avril 2019.

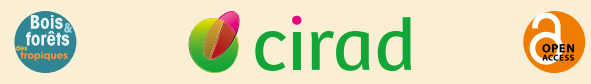

(C) $(1) \Theta$

\section{Citer l'article / To cite the article}

Sibelet N., Posada K. E., Gutiérrez-Montes I. A., 2019. Agroforestry systems provide firewood for livelihood improvement in Guatemala. Bois et Forêts des Tropiques, 340: 91-102. Doi : https://doi.org/10.19182/bft2019.340. $\underline{\text { a31692 }}$ 


\section{RÉSUMÉ}

\section{Les systèmes agroforestiers fournissent du bois-énergie qui améliore les moyens d'existence au Guatemala}

Dans le contexte du changement climatique et de la pauvreté, les populations rurales sont de plus en plus confrontées aux défis de la gestion adéquate des ressources, de la production alimentaire et de l'amélioration de la qualité de vie. Le Guatemala doit faire face au changement climatique et à la pauvreté tout en tenant compte de sa production agricole. À cet égard, les systèmes agroforestiers ont été proposés comme méthode alternative de production durable. Cet article présente une comparaison entre les systèmes agricoles conventionnels et les systèmes agroforestiers enrichis de Camotán et Jocotán. Les résultats montrent que le système agroforestier enrichi contribue à $65 \%$ du bois-énergie contre $7 \%$ pour le système conventionnel. Les familles utilisant le système agricole conventionnel ont extrait 81 \% de leur bois-énergie de la forêt, alors que les familles utilisant le système agroforestier enrichi n'en ont extrait que $32 \%$. Le bois-énergie produit par le système agroforestier enrichi offre un avantage supplémentaire aux femmes, aux enfants et aux jeunes, qui sont chargés de transporter les fagots, car ils n'ont pas à parcourir de longues distances pour approvisionner le foyer. Les familles ont construit et adapté des connaissances empiriques sur la gestion des arbres dans leurs systèmes de culture. Le système agroforestier enrichi est donc présenté comme une solution potentielle pour répondre à la demande annuelle de bois-énergie. La sécurité foncière influence la décision des familles rurales d'investir ou d'innover. Les systèmes agroforestiers jouent un rôle clef dans l'augmentation des ressources et l'amélioration de la qualité de vie.

Mots-clés : agroforesterie, bois-énergie, forêt, moyens d'existence, Maya Ch'orti', Guatemala.

\section{ABSTRACT}

\section{Agroforestry systems provide firewood} for livelihood improvement in Guatemala

Given the context of climate change and poverty, rural populations are increasingly faced with the challenges of appropriate resource management, adequate food production and improving their quality of life. Guatemala has to cope with climate change and poverty while taking its agricultural production into account. In this regard, agroforestry systems have been proposed as an alternative method of sustainable production. This article presents a comparison between conventional cropping systems and enriched agroforestry systems in Camotán and Jocotán. The results show that the enriched agroforestry system contributed to $65 \%$ of the firewood compared to $7 \%$ from the conventional cropping system. Families using the conventional cropping system extracted $81 \%$ of their firewood from the forest, while families using the enriched agroforestry system extracted only $32 \%$. The firewood produced by the enriched agroforestry system provided an additional benefit to women, children and young people tasked with carrying the bundles, in that they no longer needed to travel long distances to supply the household. Families constructed and adapted empirical knowledge on tree management into their cropping systems. The enriched agroforestry system is thus presented as a potential solution for meeting the annual demand for firewood. Land tenure security influences rural families' decision to invest or innovate. Agroforestry systems play a key role in augmenting resources and improving quality of life.

Keywords: agroforestry, fuelwood, forest, livelihood, Maya Ch'orti', Guatemala.

\section{RESUMEN}

\author{
Sistemas agroforestales proporcionan \\ leña que mejora los medios de vida en \\ Guatemala
}

Ante el contexto de cambio climático y pobreza, las poblaciones rurales enfrentan crecientes retos para gestionar adecuadamente los recursos, producir alimentos y tener mejor calidad de vida. Guatemala debe enfrentar el cambio climático y la pobreza teniendo en cuenta su producción agrícola. En este sentido, los sistemas agroforestales se han presentado como un método alternativo de producción sostenible. Este artículo presenta una comparación entre los sistemas agrícolas convencionales y los sistemas agroforestales enriquecidos en Camotán y Jocotán. Los resultados muestran que el sistema agroforestal enriquecido aporta el $65 \%$ de la leña contra $7 \%$ en el sistema convencional. Las familias que utilizan el sistema agrícola convencional extraen el $81 \%$ de su leña del bosque, mientras que las familias que utilizan el sistema agroforestal enriquecido extraen sólo el 32 \%. La leña producida por el sistema agroforestal enriquecido proporcionó un beneficio adicional a las mujeres, niños y jóvenes, que son los encargados de transportar los bultos, ya que no tuvieron que recorrer largas distancias para abastecer al hogar. Las familias construyeron y adaptaron conocimientos empíricos sobre el manejo de los árboles en sus cultivos. El sistema agroforestal enriquecido se presenta entonces como una solución potencial para satisfacer la demanda anual de leña. La seguridad de la tenencia de la tierra influye en la decisión de las familias rurales de invertir o innovar. Los sistemas agroforestales desempeñan un papel clave en aumentar los recursos y mejorar la calidad de vida.

Palabras clave: agroforestería, leña, bosque, medios de vida, Maya Ch'orti', Guatemala. 


\section{Introduction}

For decades, numerous conventions, protocols and agreements have been established on a global level in order to stop the degradation of forests and natural resources. Against a backdrop of increasing demand for natural resources, agroforestry has been presented as an alternative method of sustainable production (Nair, 1993; Beer et al., 2003). Agroforestry systems incorporate an optimal management of resources such as soil, crops, trees and vegetation. They contribute to the provision of ecosystem services, biodiversity conservation and soil improvement (Sileshi et al., 2007; FAO, 2014).

In the context of climate change and persistent poverty, rural populations are constantly faced with the challenges of adequate resource management, food production and raising the quality of life. In tropical regions such as Central America, the majority of the population depends on agriculture for their livelihood and this puts pressure on natural resources, especially forests.

Like any countries, Guatemala is a country that must cope with climate change and poverty by relying on agriculture. Guatemala ranks number 9 on the Global Climate Risk Index, which means it is a country highly impacted by extreme weather events (Kreft et al., 2014) With a total population of $16,673,000$ inhabitants, $59 \%$ of the population lives in poverty and $49 \%$ lives in rural areas (United Nations, 2017). The 2016 estimated GDP (Gross domestic product) per capita is 7,900 USD, occupying the 133rd position worldwide (CIA, 2017). In an effort to fight poverty, government agencies have developed social programs and projects that incorporate annual crops (e.g. Zero Hunger and the Food Security Program, ProRural, My Family Produces, National Rural Extension System). However, a comparative analysis between conventional cropping systems and agroforestry systems is lacking.

Agroforestry systems in Guatemala provide families and the environment with different ecosystem services, which include food for humans and animals, firewood, timber and fence posts. This reduces the pressure on forests and contributes to a better quality of life for families. In this article we pursue a comparative analysis of conventional cropping systems and enriched agroforestry systems. The question guiding our research is: what role do agroforestry systems play in comparison with conventional cropping systems in terms of livelihood improvement?
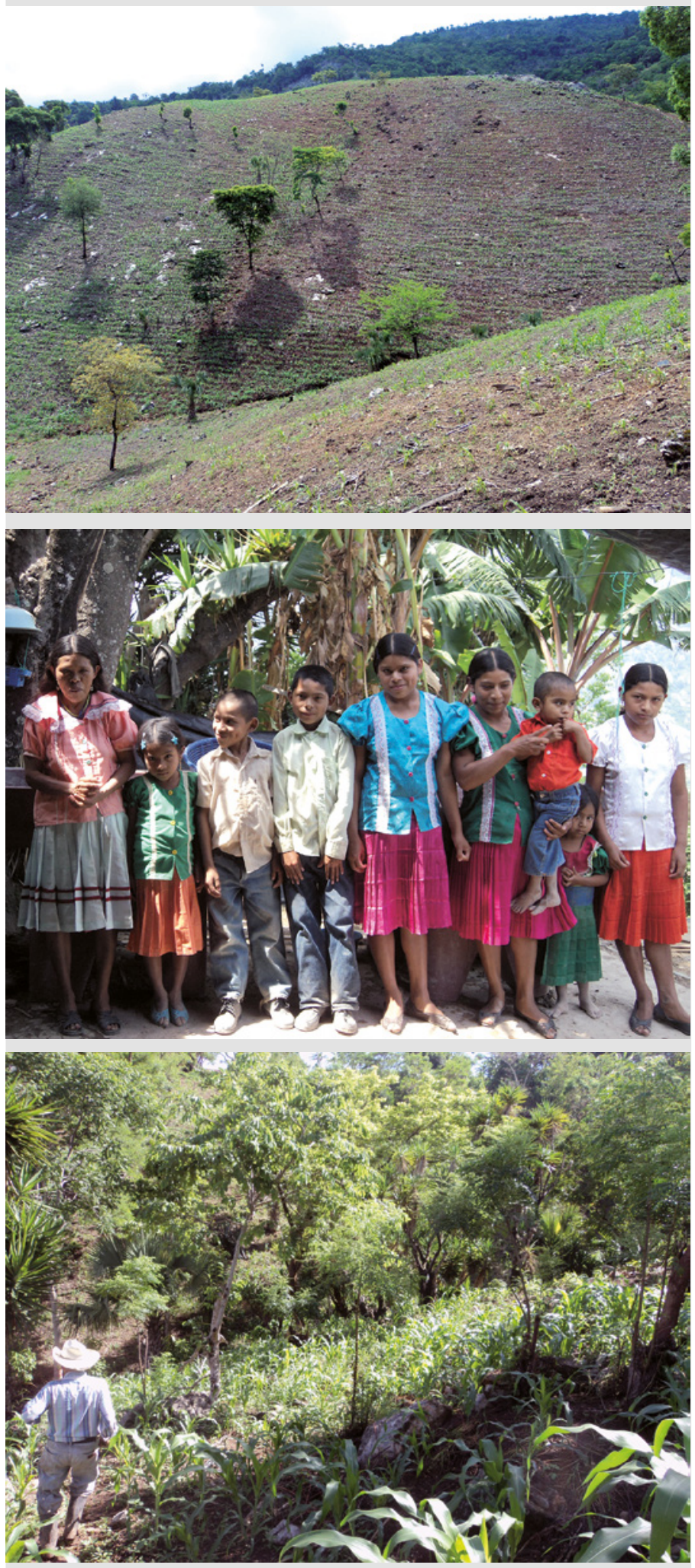

Photos 2.

Subsistence agriculture on steep slopes in the dry regions of Guatemala using maize and beans. Family from the village of Tesoro Arriba in Jocotán, gathered to celebrate the beginning of corn planting. A farmer descending a steep field planted with maize.

Photos K. Posada. 


\section{Materials and Methods}

\section{Location of the study area: Dry Corridor}

Our study was conducted in the Dry Corridor of Guatemala, in the department of Chiquimula. The Dry Corridor includes the departments of Jutiapa, Jalapa, Chiquimula, El Progreso and Zacapa (an area of $9,801 \mathrm{~km}^{2}$, or $9 \%$ of the territory of Guatemala) (PNUD, 2013). In Guatemala, a dry corridor is "a semi-arid territory characterized by prolonged droughts, a broken topography consisting of hills and mountains, shallow soils with medium to low fertility rates and a tendency for erosion" (PNUD, 2013). The Dry Corridor experienced severe drought in the past decades for which the government of Guatemala provided emergency food aid and promoted the adaptation through agricultural practices that would mitigate the impact of drought, particularly to the most food insecure families (Sain et al., 2017). Several reports of Climate Change and its effect indicate that the rural area of the dry corridor will be most affected by droughts consequently families could be exposed to crops losses and lack of food and water (Castellanos and Guerra, 2009; Gutiérrez and Espinoza, 2010; Bouroncle et al., 2015; United Nations, 2018).
The department of Chiquimula is one of the departments with a poverty rate of 79\%, higher than the 2011 national average of 54\% (INE, 2013ac). Families live of agriculture and their diets consist mainly of maize (Zea mays L.) and beans (Phaseolus vulgaris L.). These crops, usually grown in areas with steep slopes between 200 and 900 metres elevation, represent an average of $23 \%$ of calories found in the staple diet (photos 2). It is estimated that in 2012, about 110,422 tons of maize and 47,977 tons of beans were produced in Chiquimula. In addition to its nutritional value, maize plays a role in the traditions and customs in a country where $40 \%$ of the population is indigenous (INE, 2013b).

The municipalities of Camotán and Jocotán (figure 1, table I) are representative of Chiquimula department mainly through variables such as the levels of extreme poverty (1.25 USD or less per day): $41 \%$ and $59 \%$ respectively (INE, $2013 a)$. In both municipalities, $63 \%$ of the production of staple crops is done on hillsides. There is a $35 \%$ rate of food security vulnerability (PNUD, 2013). Furthermore, the Guatemalan government's Office of Planning and Programming (SEGEPLAN) reports medium and low levels in terms of quality of life. Camotán ranks 20th out of the 332 Guatemalan municipalities and Jocotán ranks last (SEGEPLAN, 2008).

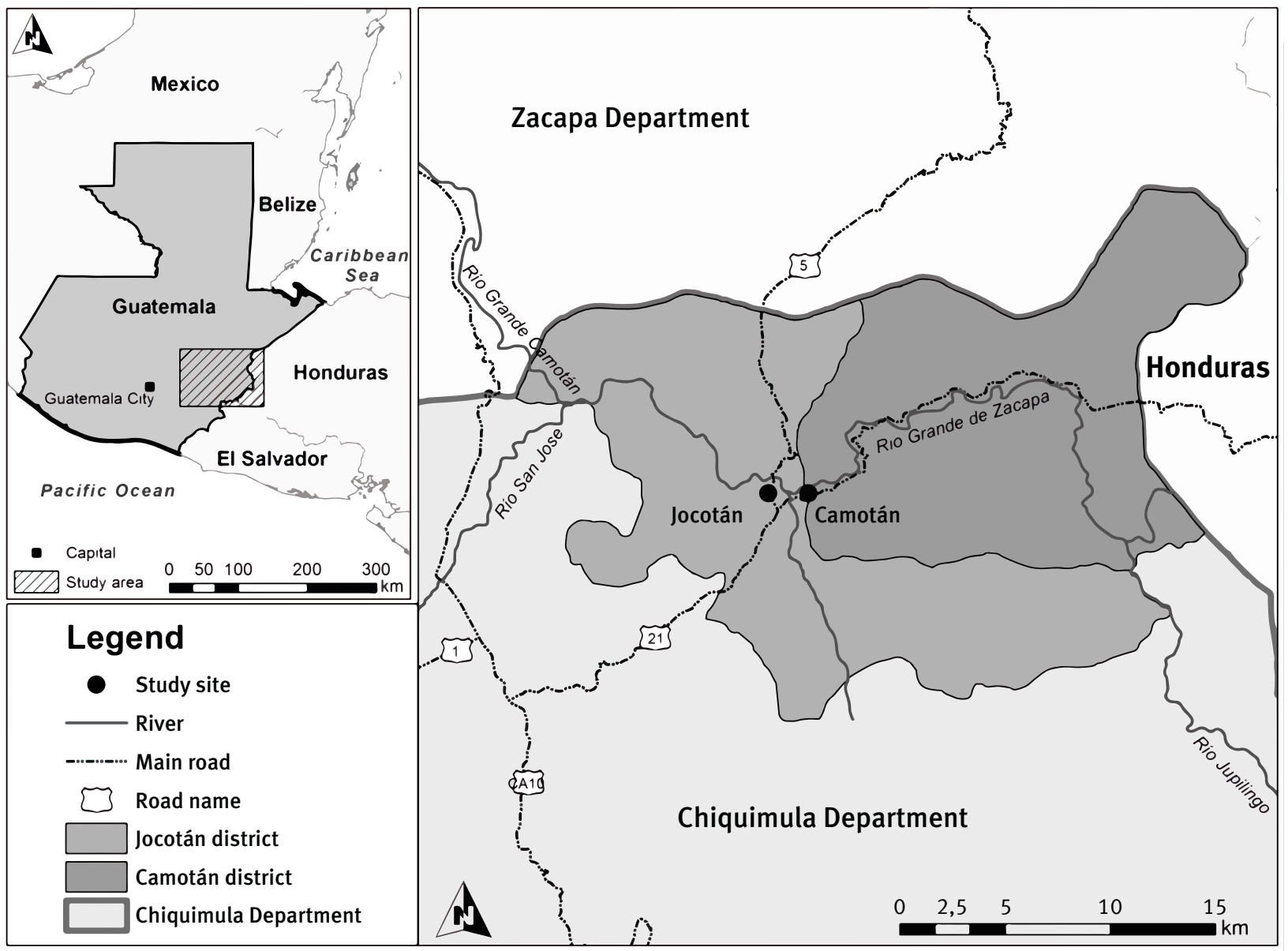

Figure 1.

Location of the study area. 
Table I.

Characteristics of the two municipalities.

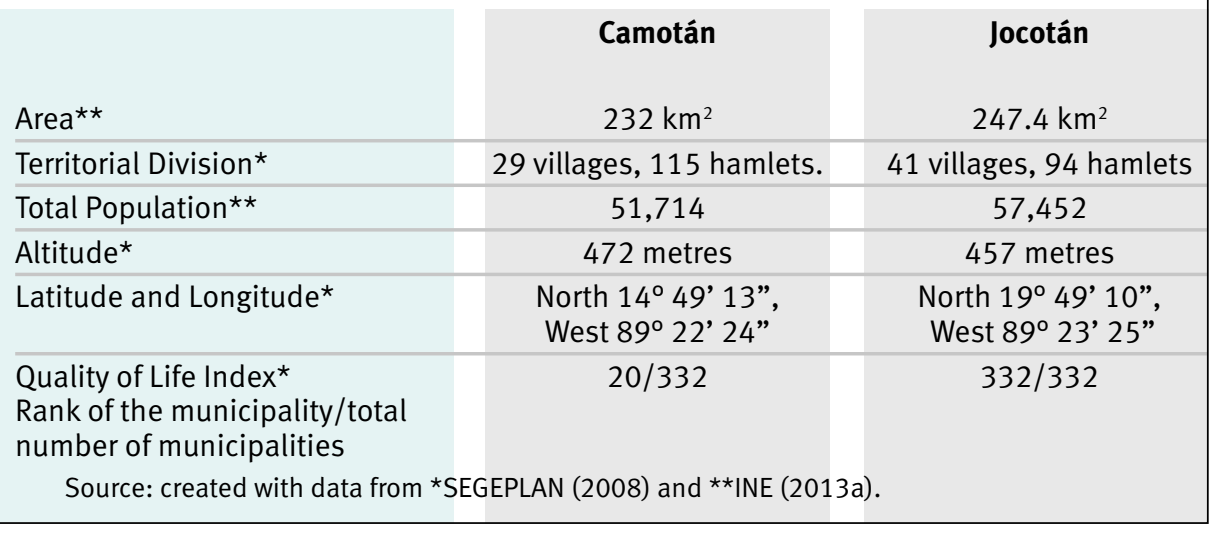

Regarding environmental characteristics, $80 \%$ of the area in both municipalities is located in a tropical area which is characterized by an average annual rainfall of 1,100-1,349 mm, with temperatures between 20 and $26^{\circ} \mathrm{C}$. The vegetation is constituted of: Pinus oocarpa Schiede, Curatella americana L., Quercus spp., Byrsonima crassifolia (L.) Kunth. On average, pasture and forestry occupy $85 \%$ of the territory of these municipalities. However, due to an increase in deforestation (with a rate of $1 \%$ per year from 2006 to 2010), the forest cover constituted $34.2 \%$ of the total land in 2012 (INAB et al., 2012).

\section{Socio-anthropological study}

\section{Conceptual Framework}

We used the concept of agroforestry systems (Nair, 1993; Nair and Latt, 1997; Beer et al., 2003), the Sustainable Livelihoods Approach (SLA) (DFID, 1999) and the
Community Capitals Framework (CCF) (Gutiérrez-Montes et al., 2009; Flora and Flora, 2013). Identifying the components of an agroforestry system sets the foundation to compare it with a conventional cropping system. The SLA uses financial, human, natural, physical and social capitals and is well-suited to local level assessments (Thulstrup, 2015). The SLA and CCF both place focus on assets (of the household or community) rather than deficiencies. The capitals of the CCF, in addition to those of the SLA, include cultural and political (Gutiérrez-Montes et al., 2009; Flora and Flora, 2013). We also used other variables such as management practices in both systems, the use of natural resources, the presence of local groups, income-generating activities, and decision-making at the household level. The selected indicators for each capital were: Land tenure for Physical capital; Firewood consumption and Sources for firewood collection for Natural capital; Production yields and Maize and bean consumption for Financial capital; Participation in local groups for Social capital; Level of education, Family size and Occupation/employment sources for Human capital; Management practices in the plots for Cultural capital.

\section{Sampling and interviews}

The study is based on socio-anthropological methods that include literature review, participant observation and semi-structured interviews (Sibelet et al., 2013) of a

Table II.

Villages of Jocotán and Camotán.

\section{JOCOTÁN}

(36 interviews: 18 conventional cropping system and 18 enriched agroforestry system)
CAMOTÁN

(38 interviews: 19 conventional cropping system and 19 enriched agroforestry system)

\begin{tabular}{|c|c|c|c|c|c|c|c|}
\hline Villages & $\begin{array}{l}\text { Total No } \\
\text { Families }\end{array}$ & $\begin{array}{c}\mathrm{N}^{\circ} \\
\text { Interviews }\end{array}$ & $\%$ & Villages & $\begin{array}{l}\text { Total No } \\
\text { Families }\end{array}$ & $\begin{array}{c}\mathrm{N}^{\circ} \\
\text { Interviews }\end{array}$ & $\%$ \\
\hline Tunucó Abajo & 49 & 2 & 4 & El Volcán & 36 & 6 & 17 \\
\hline Tesoro Arriba & 155 & 4 & 3 & Lela Obraje & 149 & 4 & 3 \\
\hline Tesoro Abajo & 28 & 4 & 14 & Guior & 94 & 6 & 6 \\
\hline Canapará Abajo & 71 & 4 & 6 & La Libertad & 136 & 6 & 4 \\
\hline Potreros & 45 & 4 & 9 & El Tesoro & 102 & 4 & 4 \\
\hline El Barbasco & 52 & 6 & 12 & Muyurcó & 32 & 4 & 13 \\
\hline Plan de Candelero & 24 & 2 & 8 & Lela Chanco & 76 & 4 & 5 \\
\hline Los Vados & 68 & 2 & 3 & El Limón & 69 & 4 & 6 \\
\hline La Arada & 60 & 2 & 3 & & & & \\
\hline La Mina & 72 & 2 & 3 & & & & \\
\hline Pacrén & 29 & 4 & 14 & & & & \\
\hline
\end{tabular}


comprehensive type (Kaufmann, 2011). We conducted 74 semi-structured interviews: 38 with families from eight villages in the municipality of Camotán and 36 with families from eleven villages in Jocotán (table II). We selected those villages with the help of the following key informants: officials of the Commonwealth of Copán Ch'orti', United Nations Food and Agriculture Organisation (FAO) Special Program on Food Security (FAO-PESA), and Tropical Agricultural Research and Higher Education Center (CATIE) Sustainable Management of Agricultural Territories Project (MESOTERRA-CATIE). Health centres and chairs of local groups identified key informants that could provide information on the two systems being compared. In addition, half of the families we interviewed in each municipality used an enriched agroforestry system and half did not, maintaining a conventional cropping system. We characterized these two systems and compared them in reference to the promoted one by the project FAO-PSEA. We recognize that so-called conventional cropping systems have agroforestry components: some plots have a few trees mainly on the boundaries (photos 3). These trees remain marginal, so we will name this system here as conventional cropping system to distinguish it from the new system practiced, clearly enriched with trees, that we call the "enriched agroforestry system".

We selected the interviewed families based on information given by a community representative, the president of the Community Development Council (COCODE) in each municipality. In order to select the plots for all interviews we used the following criteria: more than one tree species planted within maize and bean crops (or in hedges), management practices (pruning, mulching, no slash-andburn), and land tenure (owners and tenants).

We used several methods simultaneously to analyse the data. We used descriptive statistics such as averages, percentages and absolute frequencies plus dynamic tables to do comparisons and classification between the two systems.

Select quotations from interviewees highlight the richness of the qualitative information obtained.

\section{Results and Discussion}

\section{The history of the agroforestry system in Camotán and Jocotán}

Starting in 1999 for five years, the FAO-PESA developed projects in Guatemalan municipalities with socio-environmental vulnerability, acute malnutrition and famines (FAO-PESA, 2009). Particularly in the municipalities of Camotán y Jocotán, agroforestry systems were promoted through alley-cropping, using rows of Gliricidia sepium in association with maize and beans (FAO, 2014). The agroforestry system promoted by FAO-PESA in this region is called "Kuxur Rum", a Maya Ch'orti' term meaning "My Wet Land" ("Mi tierra Húmeda" in Spanish) (FAO-PESA, 2009).

The alley-cropping agroforestry system was implemented due to the terrain's topography and degraded soil conditions. The alley of $G$. sepium acted as a living
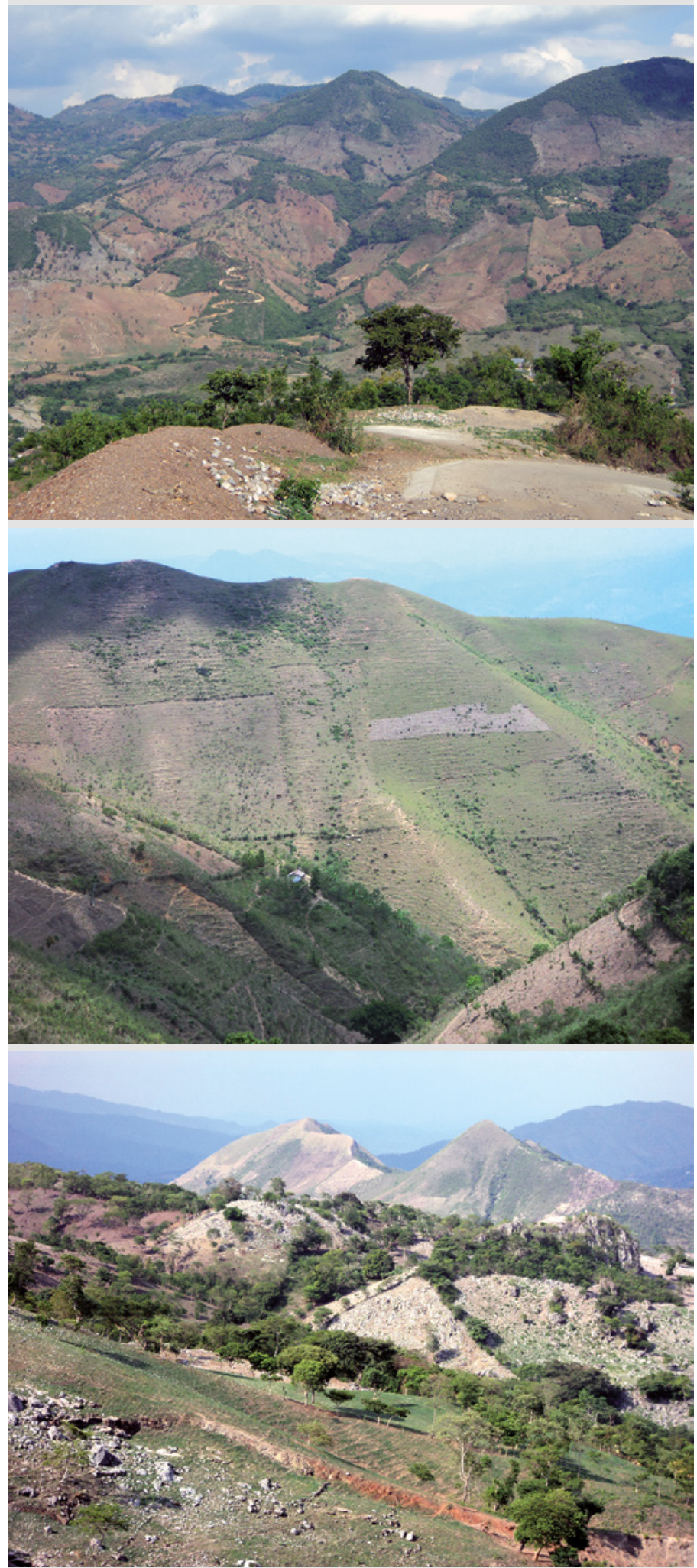

Photos 3.

Landscape with conventional cropping system based on maize and bean crops in Camotán and Jocotán.

Photos K. Posada. 
barrier, favouring water conservation and soil improvement (FAO-PESA, 2009; FAO, 2014). During the project, the families involved applied these practices to their fields. Alley cropping agroforestry technologies selected the few tree species used based on characteristics such as high yield, rapid growth or nitrogen fixation, e.g. Leucaena leucocephala (Lam.) de Wit or G. sepium (Atta-Krah et al., 2004). However, in using these technologies, the low genetic diversity increases the whole system's vulnerability to plagues or illnesses (Atta-Krah et al., 2004).

Camotán and Jocotán are municipalities of Mayan Ch'orti' ethnicity. However, the interviewees did not use the name "Kuxur Rum" when designating the agroforestry system as the FAO does. They associated the name "Kuxur Rum" to G. sepium (Madre de Cacao) and the practices linked to it. Fifty-three percent of interviewees associated the "Kuxur Rum" agroforestry system to "planting Madre de Cacao to improve the soil", "integrating trees and crops", "using Madre de Cacao to protect the soil from erosion, provide firewood and fertilise the ground".

Over time families modified the more rigid and less biodiverse agroforestry system proposed by FAO to one that included different species of timber and fruit trees in a dispersed layout on their land. This exemplifies that families constructed and adapted empirical knowledge concerning tree management into their cropping systems.

\section{Characteristics of the agricultural systems encountered}

In Camotán and Jocotán, we encountered two agricultural systems established on lands smaller than one hectare: the conventional cropping system and the enriched agroforestry system. The conventional cropping system included typical crop management methods: two crops per year, an association of maize and beans, weed management, no use of slash-and-burn, and trees mainly on the boundaries (table III). The enriched agroforestry system combined the use of different species of trees planted amongst the maize and beans (table III), with soil conservation practices such as no-till, incorporation of organic matter, no slash-and-burn, propagation by cutting or caring for the naturally regenerating species, and shade management through annual pruning (FAO-PESA, 2009; FAO, 2014). Although the most common layout consisted of "crops under tree cover" (Torquebiau et al., 2002), we also encountered trees in alley cropping and living fences (table IV). The latter agroforestry practice mentioned here is the second of eight most frequently used practices cited in a study about climate-smart agriculture in the Dry Corridor (Sain et al., 2017).

We found that producers most commonly grew G. sepium (Jacq.) Walp. ("Madre de Cacao"). Thus, we define the type of agroforestry system found as: the dispersed association of trees of different species, primarily G. sepium but also other timber, fruit or other species with maize and bean crops. The practices used are frequent pruning, incorporating the clippings into the soil and not using slash-and-burn.

Given its many uses, G. sepium is a critical tree species in the enriched agroforestry systems encountered in this study. Interviewees pointed out that this species has multiple uses: provides firewood, timber, shade and fertiliser; it grows rapidly and is resistant; the clipped branches obtained from pruning can be replanted in the plots or shared with neighbours; and the leaves are used on the ground as mulch. All of these uses were encountered in The Comoros, where G. sepium is used for living fences as part of the bocage and protects the ground from erosion (Sibelet, 1995). Moreover, $G$. sepium is a resistant species that adapts to degraded soils and contributes to their regeneration in a variety of ecosystems (Kabwe et al., 2009). According to several authors, these practices exist within the Quesungual agroforestry system in Lempira, Honduras (Ayarza et Welches, 2004). This system is characterised by the association of native tree species to annual crops such as maize, beans, sorghum (Sorghum spp.) and pastures. The trees are pruned periodically and the clippings are incorporated into the soil for moisture retention and fertility purposes. The crops are established using no-till and without the practice of slash-and-burn (Ayarza and Welches, 2004; FAO, 2005). 


\begin{tabular}{|c|c|c|}
\hline \multicolumn{3}{|c|}{$\begin{array}{l}\text { Table IV. } \\
\text { Tree layout in the enriched agroforestry system }(n=38) \text {. }\end{array}$} \\
\hline Layouts & $\mathbf{n}$ & $\%$ \\
\hline Dispersed & 27 & 71 \\
\hline Alley cropping & 5 & 13 \\
\hline Dispersed + alley cropping & 2 & 5 \\
\hline Dispersed + living fences & 2 & 5 \\
\hline Alley cropping + living fences & 1 & 3 \\
\hline Dispersed + alley cropping + living fences & 1 & 3 \\
\hline Total & 38 & 100 \\
\hline
\end{tabular}

\section{Ecosystem services provided by the enriched agroforestry} system

The agriculture developed by families in Camotán and Jocotán was mainly for subsistence (maize and bean crops). The integration of different tree species on the farms and management practices associated with agroforestry practices provided ecosystem services that contribute to the improvement of livelihoods especially in terms of financial, human and cultural capital. However, the incorporation of agroforestry practices depends on access to natural resources (natural capital), inputs, incentives and support programs (Sileshi et al., 2007; Akinnifesi et al., 2008). Research in Africa demonstrated that the introduction of legumes on farms had improved the production of fodder, firewood, timber and germplasm (Akinnifesi et al., 2008). Furthermore, it was found that agroforestry systems provided services such as the modification of the microclimate, erosion control, mitigation of desertification, carbon capture, plague control, biodiversity conservation and pollination (Sileshi et al., 2007). On our investigation sites, we found that families using the enriched agroforestry system were able to identify two benefits that were not encountered in the conventional cropping system. These were: a) the contribution of the agroforestry system to the livelihoods of the families (human, social, cultural and financial capital) and b) the contribution of the agroforestry system to the ecosystem (natural capital).

Agroforestry plots provided maize and beans for self-consumption. The yield of crops per hectare varied between the two systems. The enriched agroforestry system yielded $26 \%$ more maize and $27 \%$ more beans than the conventional cropping system (table V).

Once they had provided for their families, the producers using the enriched agroforestry system have, on average, larger quantities of maize to feed their animals (e.g. hens, ducks or pigs). Families usually shared maize with their neighbours in times of famine and during village celebrations (social and cultural capital). The enriched agroforestry system produced 2.5 times more maize to share than the conventional cropping system (table V).

The families included fruit trees within their maize and bean crops (Byrsonima crassifolia (L.) Kunth, Mangifera

Table V.

Benefits of the conventional and enriched agroforestry agricultural systems $(n=74)$.

\section{Ecosystem services}

\section{Enriched agroforestry system (1)}

\section{Conventional cropping system (2)}

\section{Increased yield of enriched agroforestry system compared to conventional cropping system (\%) $(3=1 / 2)$}

Family consumption

\begin{tabular}{|c|c|c|c|}
\hline Maize & $763.72 \mathrm{~kg}$ & $604.80 \mathrm{~kg}$ & $26 \%$ \\
\hline Bean & $349.16 \mathrm{~kg}$ & $275.82 \mathrm{~kg}$ & $27 \%$ \\
\hline Firewood produced & $2.34 \mathrm{~m}^{3}$ & $0.25 \mathrm{~m}^{3 *}$ & $89 \%$ \\
\hline Firewood consumed & \multicolumn{2}{|c|}{$3.62 \mathrm{~m}^{3}$} & \\
\hline $\begin{array}{l}\text { Firewood produced/ } \\
\text { firewood consumed (\%) }\end{array}$ & $65 \%$ & $7 \%$ & \\
\hline
\end{tabular}

Additional consumption

\begin{tabular}{lccc}
\hline Maize for the animals & $145.03 \mathrm{~kg}$ & $115.10 \mathrm{~kg}$ & $26 \%$ \\
\hline Maize to share in community & $19.05 \mathrm{~kg}$ & $7.71 \mathrm{~kg}$ & $147 \%$ \\
\hline festivities or with neighbours & & & $(2.5 \mathrm{times}$ mo
\end{tabular}

festivities or with neighbours

\section{Other services}

Fruits

Timber

Green fertilisers (leaves and clippings)

Shade and resting places

Maguey and palm to elaborate artisanal crafts

Palm for the construction of houses

Moisture retention

Aesthetic value

* Firewood obtained from the borders of the land or from a few trees inside the plot. 
indica L., Citrus sinensis L., Citrus limonum Risso, Mammea americana L., Manilkara chicle (Pittier) Gilly, which contributed to the family's diet (human capital). Occasionally these trees produced surplus generating an income for the family (financial capital). In the villages of Canapará Abajo, Tunucó Abajo and Potreros (Jocotán) some families added species such as maguey, palm and wild pineapple to their crops (Agave americana L., Sabal guatemalensis Becc., Bromelia pinguin L.) (photos 4). These were used in the production of artisanal crafts (hammocks, nets, ropes and brooms), and palm was also utilised in the construction of houses (cultural, financial and built capital) (table V). A diversity of species available for household use is also a characteristic of coffee agroforestry systems in Oaxaca, Mexico where Aguilar-Støen et al. (2011) found that $64 \%$ of the plant species used were obtained from coffee forest gardens.

The families highlighted the aesthetic (cultural and human capital) dimension and the contribution to quality of life provided by the enriched agroforestry system: "Having trees in the plot means I have a place to rest when I bring food to my husband, and they (husband, sons or employees) can rest a little under the shade"; "The soil is fertilised, the plot looks nice and you see the earth change as the leaves are left on the ground"; "I like seeing the plot entirely green due to the trees, I feel happy, a treeless plot is very sad, everything is dry" (table V).

In addition to these crops, the families also sold their men's labour to coffee plantations (table VI). While $49 \%$ of the producers using the conventional cropping system sold their labour, only $15 \%$ of those who use the enriched agroforestry system did so. In the latter system, the families combined the sale of their labour with activities such as their own coffee plantations, maize and bean crops, the elaboration and sale of artisanal crafts, and family businesses such as grocery stores.

In Camotán and Jocotán, trees were the principal source of firewood for cooking. The trunks were used as poles for the construction and reparation of houses and fences. An average household consumed $3.62 \mathrm{~m}^{3}$ of firewood per year. The enriched agroforestry system supplied $65 \%$ of the firewood consumed by the families (table VII). Research shows that agroforestry systems provide large quantities of firewood. On farms in Chagga, Tanzania, the production of firewood is estimated at 1.5 to $3 \mathrm{~m}^{3}$ per hectare per year, which supplies 25 to $33 \%$ of the households' firewood needs (Sileshi et al., 2007). The households using the conventional cropping system obtained $7 \%$ of their firewood from the trees on the edge of their plots. Families using the conventional cropping system extracted $81 \%$ of their firewood from the forest, while families using the enriched agroforestry system extracted only $32 \%$ (table VII). The firewood produced by the enriched agroforestry system provided an additional benefit to women, children and youth, who are the ones in charge of carrying the bundles, in that they did not need to travel long distances to supply the household.

There are a plethora of agroforesty systems as well as decisions leading up to their implementation. Agroforesty systems' contribution to ecosystem services also varies. A study by Atta-Krah et al. (2004) shows that family decisions
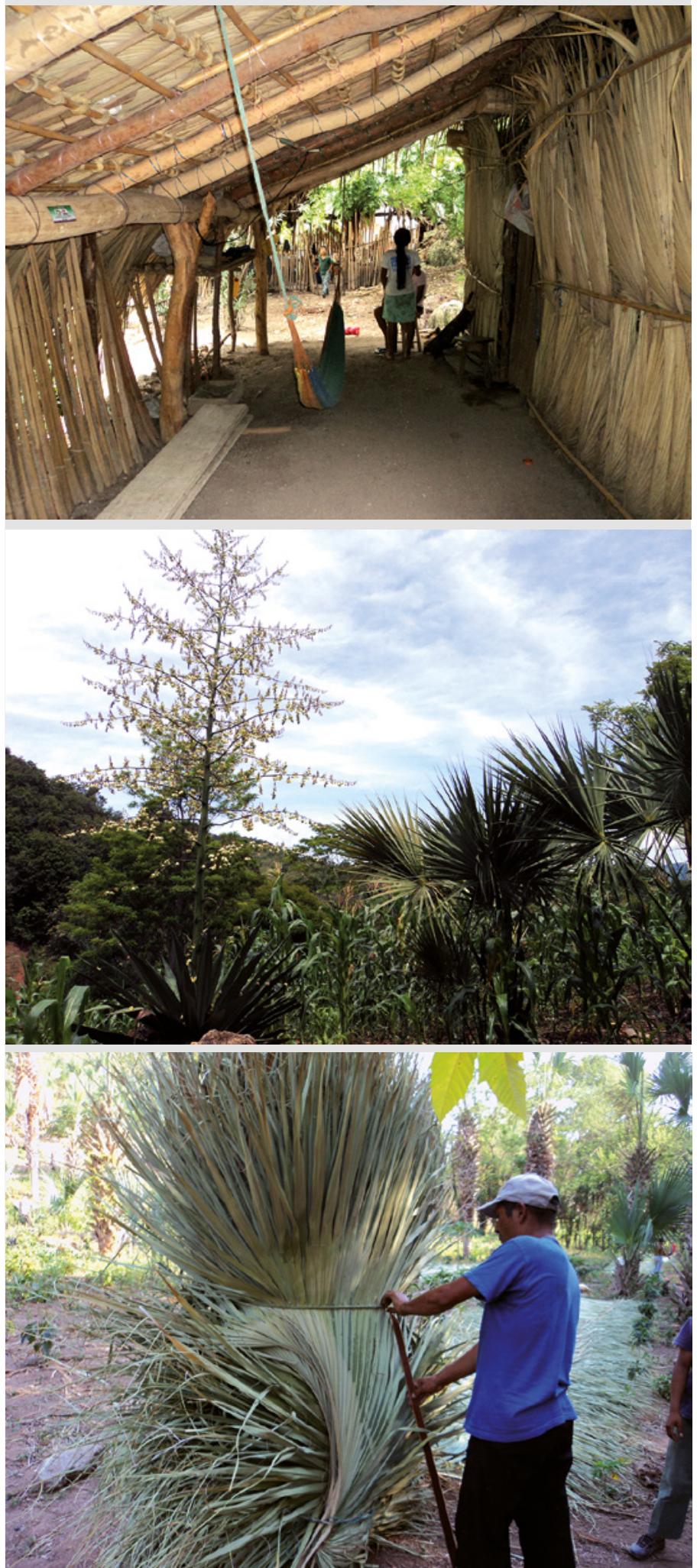

Photos 4.

Combinations of palma and maguey in the enriched agroforestry system in Camotán and Jocotán, sources of raw material for house construction and craft production.

Photos K. Posada. 
Table VI.

Combination of income generating activities $(n=67)$.

\section{Number and \\ $\%$ of farms}

\section{Enriched agroforestry system}

\section{Conventional cropping system}

\section{Sales}

Labour

Labour + coffee

Other*

$n$

Not selling (labour)

Labour + maize + bean

Labour + bean

Coffee

Labour + family business

Labour + bean + coffee + artisanal crafts + maize

Labour + artisanal crafts

Maize + bean

Total

$\%$

n $\%$

\begin{tabular}{|c|c|c|c|}
\hline 5 & 15 & 16 & 49 \\
\hline 5 & 15 & 4 & 12 \\
\hline 4 & 12 & 3 & 9 \\
\hline 2 & 6 & 3 & 9 \\
\hline 3 & 8 & 2 & 6 \\
\hline 2 & 6 & 2 & 6 \\
\hline 3 & 8 & 1 & 3 \\
\hline 4 & 12 & 1 & 3 \\
\hline 2 & 6 & 1 & 3 \\
\hline 2 & 6 & 0 & \\
\hline 2 & 6 & 0 & \\
34 & 100 & 33 & 100 \\
$\begin{array}{l}\text { 34 } \\
\text { enriched agroforestry system (beans, }\end{array}$ \\
$\begin{array}{l}\text { ans). For those using the conventional } \\
\text { affee; labour + maize + artisanal crafts. }\end{array}$ \\
\hline
\end{tabular}

they produced. Given that implementing an agroforestry system involves calculable risk for smallholder farmers (Jerneck and Olsson, 2013), it is not surprising that among families who are land tenure insecure, fewer have incorporated trees into their plots. Similarly, in the Democratic Republic of Congo, Peltier et al. (2014) demonstrated that the lack of land tenure security is one of the main factors limiting farmers' incorporation of Assisted Natural Regeneration practices (human protection and preservation of natural tree seedlings) in slash-and-burn agriculture. The development of technologies or sustainable management practices are associated with wealth and land tenure as seen in Zambia (Kabwe et al., 2009). Farmers with greater resources have the potential to cultivate more land and invest in sustainable technologies (Kabwe et al., 2009). Access to land enables families to increase other capitals (Flora and Flora, 2013). For example, land tenure security improves natural capital and produces a greater quantity and diversity of food for self-consumption. In Central America, it is estimated that $63 \%$ of farmers cultivate their own land and that $37 \%$ rent or borrow land (FAO, 2014). Similar importance is attributed to tree tenure, though rarely considered (Saïd and Sibelet, 2004). On another note, access to trees regarding the integration of tree species into their crops are linked to their strategies and income. In the medium term, these decisions result in a greater genetic diversity, providing a greater benefit to the human populations and the ecosystem (Atta-Krah et al., 2004). Benton Hite et al. (2017) study in Oaxaca, Mexico shows that the more a coffee agroforestry system is managed the less it contributes to ecosystem services in terms of tree species biodiversity.

\section{Land tenure determines the implementation of the agroforestry system}

Land tenure was fundamental in establishing an agroforestry system (human, political, financial and built capital) (table VIII). Eighty-one percent (81\%) of families that incorporated trees into their maize and bean plots were landowners. On the contrary, $61 \%$ of the families using the conventional cropping system rented the land on which

Table VII.

Household firewood consumption and sourcing $(n=74)$.

\begin{tabular}{|c|c|c|c|c|}
\hline \multirow[t]{2}{*}{ System } & \multicolumn{4}{|c|}{ Sources of firewood } \\
\hline & $\begin{array}{c}\% \\
\text { farmer's } \\
\text { plot }\end{array}$ & $\begin{array}{c}\% \\
\text { forest }\end{array}$ & $\begin{array}{c}\% \\
\text { bought }\end{array}$ & $\begin{array}{c}\% \\
\text { Total }\end{array}$ \\
\hline Enriched agroforestry & 65 & 32 & 2 & 100 \\
\hline Conventional cropping & $7^{*}$ & 81 & 12 & 100 \\
\hline
\end{tabular}

can be strictly linked to land tenure; the person who plants the tree and looks after it does not necessarily have a right to use it (Farrell and Altieri, 1997).

\section{Conclusion}

The enriched agroforestry system found in Camotán and Jocotán offered greater benefits for families and forests compared to the conventional cropping system in terms of improving and increasing access and control over resources. This is important for a country like Guatemala, which suffers from persistent multidimensional poverty and is recognized by its vulnerability to climate change. We found that the enriched agroforestry system provided $65 \%$ of the firewood, while the conventional cropping system provided $7 \%$. Additionally, the former provided $26 \%$ more maize than the latter. Fifteen percent (15\%) of the families using the enriched agroforestry system sold their labour compared to $48 \%$ in the conventional cropping system.

In Camotán and Jocotán, land tenure security was a determining factor for environmental sustainability. The $81 \%$ of farmers with the enriched agroforestry system are owners while only $33 \%$ of farmers who have the conventional cropping system are owners.

The families built empirical knowledge regarding tree management into their cropping systems. They transformed the original FAO-proposed agroforestry system, which used alley cropping and just one tree species (G. sepium) into an enriched agroforestry system that incorporated a great variety of tree species in a 
Table VIII.

Land tenure in the different systems $(n=74)$

\begin{tabular}{|c|c|c|c|c|c|c|}
\hline \multirow{3}{*}{ System } & \multicolumn{6}{|c|}{ Land Tenure } \\
\hline & \multicolumn{2}{|c|}{ Owned } & \multicolumn{2}{|c|}{ Rented } & \multicolumn{2}{|c|}{ Borrowed } \\
\hline & $\mathbf{n}$ & $\%$ & $\mathbf{n}$ & $\%$ & $\mathbf{n}$ & $\%$ \\
\hline $\begin{array}{l}\text { Enriched agroforestry } \\
(n=38)\end{array}$ & 31 & 81 & 6 & 16 & 1 & 3 \\
\hline $\begin{array}{l}\text { Conventional cropping } \\
(\mathrm{n}=36)\end{array}$ & 12 & 33 & 22 & 61 & 2 & 6 \\
\hline
\end{tabular}

dispersed layout, thus providing multiple benefits. The latter agroforestry system provides ecosystem services which enable families to diversify their income (monetary and non-monetary) and better adapt to the environmental conditions of the dry corridor.

The enriched agroforestry system in this study has the potential to satisfy the annual household demand for firewood and therefore could be an incentive for forest and biodiversity conservation in rural areas. Nonetheless, we recognise that non-landowning families are obtaining firewood from the borders of the land or from the few trees inside the plots they rent or borrow. Finally, the agroforestry system promotes local integration, a poorly recognised but vitally important cultural service regarding the ways in which families are responding to the effects of climate change. Agroforestry systems are an adaptable option with the potential to be developed at a territorial level in order to provide a livelihood for the inhabitants whilst lowering the pressure on forests.

\section{Acknowledgements}

We are grateful to the families of the nineteen villages of Camotán and Jocotán for their time, knowledge sharing and their willingness to collaborate. Thanks to the Real Embassy of Norway for their funding and to the Mesoamerican Agro-environmental Program for their institutional support. We would also like to thank Muhammad Ibrahim, Alejandro Imbach, Danilo Padilla and Julio López for their help with the research. We are grateful to Alix Villanueva and Casi Avard for translating and editing.

\section{References}

Aguilar-Støen M., Angelsen A., Stølen K.-A., Moe S. R., 2011. The emergence, persistence, and current challenges of coffee forest gardens: A case study from Candelaria Loxicha, Oaxaca, Mexico. Society \& Natural Resources, 24 (12): 1235-1251. https://doi.org/10.1 080/08941920.2010.540309

Akinnifesi F. K., Sileshi G., Ajayi O. C., Chirwa P. W., Kwesiga F. R., Harawa R., 2008. Contributions of agroforestry research and development to livelihood of smallholder farmers in Southern Africa: 2. Fruit, medicinal, fuelwood and fodder tree systems. Agricultural Journal, 3: 76-88. http://medwelljournals.com/abstract/?doi=aj.2008.76.88
Atta-Krah K., Kindt R., Skilton J. N., Amaral W., 2004. Managing biological and genetic diversity in tropical agroforestry. Agroforestry Systems, 61: 183-194. http://www. worldagroforestry.org/downloads/Publications/PDFS/ ja04027.pdf

Ayarza M. A., Welches L. A., 2004. Drivers affecting the development and sustainability of the Quesungual slash and mulch agroforestry system (QSMAS) on Hillsides of Honduras. In: Noble A. (éd.). Comprehensive Assessment Bright Spots Project Final Report, Colombo, Sri Lanka, IWMI, 187-201. https://cgspace.cgiar.org/handle/10568/21814

Beer J., Harvey C. A., Ibrahim M., Harmand J. M., Somarriba Chavez E., Jimenez F., 2003. Servicios ambientales de los sistemas agroforestales. Agroforestería en las Américas, 10: 80. http://publications.cirad.fr/une notice.php?dk=519173

Benton Hite E., Barton Bray D., Duran E., Rincón-Gutiérrez A., 2017. From forests and fields to coffee and back again: Historic transformations of a traditional coffee agroecosystem in Oaxaca, Mexico. Society \& Natural Resources, 30 (5): 613-626. https://doi.org/10.1 $\underline{080 / 08941920.2016 .1239291}$

Bouroncle C., Imbach P., Läderach P., Rodríguez B., Medellín C., Fung E., et al., 2015. La agricultura de Guatemala y el cambio climático: ¿Dónde están las prioridades para la adaptación? Copenhague, Dinamarca, CGIAR Research Program on Climate Change, Agriculture and Food Security (CCAFS), 8 p. https://hdl.handle. net/10568/45942

Castellanos E., Guerra A., 2009. El cambio climático y sus efectos sobre el desarrollo humano en Guatemala. Cuadernos de desarrollo humano. United Nations Development Programme, New York, 51 p. https://www.researchgate.net/profile/Edwin Castellanos/ publication/266578184_El_cambio_climatico_y_sus_efectos sobre_el_desarrollo humano_en_Guatemala/links/54be786a0cf218d4a16a63a5.pdf

CIA, 2017. GDP - per capita (PPP) 2017 Country Ranks, By Rank, CIA World Factbook 2017. USA, CIA. https://www.cia.gov/library/publications/the-world-factbook/rankorder/2004rank.html

DFID, 1999. Sustainable livelihoods guidance sheets. UK, DFID Department for International Development. https://www.ennonline.net/dfidsustainableliving

FAO-PESA, 2009. En Huité, familias conviven con la sequía. FAO, 7 p. http://www.fao.org/3/a-at781s.pdf

FAO, 2005. El sistema agroforestal Quesungual. Una opción para el manejo de suelos en zonas secas de laderas. Organización de las Naciones Unidas para la Alimentación y la Agrícultura, Roma, Italia, 50 p. http://www.fao.org/3/a-at763s.pdf

FAO, 2014. Los programas PESA de Centroamérica: quince años de cooperación para la seguridada alimentaria y nutricional. Logros y lecciones aprendidas, Hambre de saber, saber de hambre, 203 p. http://www.fao.org/3/a-i4323s.pdf

Farrell J. G., Altieri M. A., 1997. Sistemas agroforestales. In: Altieri M. A. (éd.). Agroecología. Bases científicas para una agricultura sustentable. La Habana, Cuba, CLADES/ACAO, 229-243. https:// fr.scribd.com/document/51064434/Altieri-Miguel-Agroecologia-Bases-Cientificas-para-una-Agricultura-Sustentable 
Flora C., Flora J. L., 2013. Rural Communities: Legacy + Change. Boulder, Colorado, USA, Westview Press, 372 p.

Gutiérrez M. E., Espinosa T., 2010. Vulnerabilidad y adaptación al cambio climático. Diagnóstico inicial, avances, vacíos y potenciales líneas de acción en Mesoamérica, Notas técnicas. Banco Interamericano de Desarrollo (BID). Unidad de Energía Sostenible y Cambio Climático, Departamento de Infraestructura y Medio Ambiente, 84 p. https://www.uncclearn.org/sites/default/files/inventory/ idb21_spn.pdf

Gutiérrez-Montes I., Emery M., Fernandez-Baca E., 2009. The sustainable livelihoods approach and the community capitals framework: The importance of system-level approaches to community change efforts. Community Development, 40: 106-113. http://dx. doi.org/10.1080/15575330903011785

INAB, CONAP, URL-IARNA, UVG, 2012. Mapa de cobertura forestal de Guatemala 2010 y dinámica de la cobertura forestal 2006-2010. Instituto Nacional de Bosques, Guatemala, Guatemala, 114 p. https://www.researchgate.net/publication/281861610_Mapa de cobertura forestal de Guatemala 2010 y dinamica de la cobertura forestal 2006-2010

INE, 2013a. Caracterización departamental de Chiquimula 2012. Instituto Nacional de Estadísticas, Guatemala, Guatemala, 74 p. https://www.ine.gob.gt/sistema/uploads/2013/12/09/IdAiQPEvPhCxVPz9sumuZmbPlyXva1Dx.pdf

INE, 2013b. Caracterización estadística de la república de Guatemala 2012. Instituto Nacional de Estadísticas, Guatemala, 76 p. https://www.ine.gob.gt/sistema/uploads/2014/02/26/5eTCcFlHErnaNVeUmm3iabXHaKgXtw0C.pdf

INE, 2013c. Mapas de pobreza rural en Guatemala 2011. Resumen ejecutivo. Instituto Nacional de Estadísticas, Guatemala, Guatemala, 24 p. https://www.ine.gob.gt/sistema/uploads/2014/01/10/ifRRpEnfOcjUfRZGhyXD7RQjf7EQH2Er.pdf

Jerneck A., Olsson L., 2013. More than trees! Understanding the agroforestry adoption gap in subsistence agriculture: Insights from narrative walks in Kenya. Journal of Rural Studies, 32: 114-125. https://doi.org/10.1016/i.jrurstud.2013.04.004

Kabwe G., Bigsby H. R., Cullen R., 2009. Factors influencing adoption of agroforestry among smallholder farmers in Zambia. In: New Zealand Agricultural and Resource Economics Society Conference, 25-27 August 2006, Lincoln University, Lincoln, New Zealand. http://researcharchive.lincoln.ac.nz/bitstream/handle/10182/3425/20099 Zambian Agroforestry Adoption KabweG.pdf?sequence $=1$

Kaufmann J.-C., 2011. L'entretien compréhensif. Paris, Armand Colin, 128 p.

Kreft S., Eckstein D., Junghans L., Kerestan C., Hagen U., 2014. Global climate risk index 2015: Who suffers most from extreme weather events? Weather-related loss events in 2013 and 1994 to 2013. Think Tank \& Research. Germanwatch e.V., Bonn, Germany, 32 p. https://germanwatch.org/de/download/10333.pdf

Nair P. R., 1993. An introduction to agroforestry. Berlin, Germany, Springer Science \& Business Media, 489 p. https://www.worldagroforestry.org/Units/Library/Books/PDFs/32_An_introduction_to agroforestry.pdf? $n=161$

Nair P. R., Latt C. R., 1997. Directions in tropical agroforestry research. Kluwer Academic Publishers, Springer, 250 p. https:// link.springer.com/book/10.1007\%2F978-94-015-9008-2
Peltier R., Diowo S., Gigaud M., Marien J-N., Marquant B., Péroches A., et al., 2014. Assisted Natural Regeneration in slash-and-burn agriculture: Results in the Democratic Republic of the Congo. Bois et Forêts des Tropiques, (321): 67-79. https://doi.org/10.19182/ bft2014.321.a31220

PNUD, 2013. Evaluación del bienestar humano y ambiente en el corredor seco oriental de Guatemala Programa Naciones Unidas para el Desarrollo. Informe Final (9929-8134). Programa Naciones Unidas para el Desarrollo, Guatemala, 81 p. http://unpei.org/sites/ default/files/e library documents/Evaluation\%20 of\%20Environment $\% 20$ and $\% 20$ Human $\% 20$ Wellbeing $\% 2$ C $\% 20$ Dry $\% 20$ Corridor\%2C\%20Guatemala\%2C\%202013\%20.pdf

Saïd M., Sibelet N., 2004. Pour que la terre ne cache plus l'arbre : le foncier de l'arbre. Cahiers Agricultures, 13 : 510-515. http:// agritrop.cirad.fr/523213/

Sain G., Loboguerrero A. M., Corner-Dolloffa C., Lizarazo M., Nowak A., Martínez-Barón D., et al., 2017. Costs and benefits of climate-smart agriculture: The case of the Dry Corridor in Guatemala. Agricultural Systems, 151: 163-173. https://doi.org/10.1016/i. agsy.2016.05.004

SEGEPLAN, 2008. Vulnerabilidades de los municipios y calidad de vida de sus habitantes. Secretaría de Planificación y Programación de la Presidencia de la República, Guatemala, 77 p.

Sibelet N., 1995. L'innovation en milieu paysan ou la capacité des acteurs locaux à innover en présence d'intervenants extérieurs. Nouvelles pratiques de fertilisation et mise en bocage dans le Niumakélé (Anjouan Comores). Thèse de doctorat : Sociologie rurale, Institut national agronomique Paris-Grignon, Grignon, France, 400 p. http://agritrop.cirad.fr/301960/

Sibelet N., Mutel M., Arragon P., Luye M., 2013. Qualitative survey methods applied to natural resource management. Online learning modules. http://entretiens.iamm.fr/

Sileshi G., K. Akinnifesi F., Ajayi O. C., Chakeredza S., Kaonga M., Matakala P. W., 2007. Contributions of agroforestry to ecosystem services in the Miombo eco-region of eastern and southern Africa. African Journal of Environmental Science and Technology, 1: 68-80. https://www.ajol.info/index.php/ajest/article/ viewFile/135037/124545

Thulstrup A. W., 2015. Livelihood resilience and adaptive capacity: Tracing changes in household access to capital in Central Vietnam. World Development, 74: 352-362. http://dx.doi.org/10.1016/j. worlddev.2015.05.019

Torquebiau E., Mary F., Sibelet N., 2002. Les associations agroforestières et leurs multiples enjeux. Bois et Forêts des Tropiques, 271 : 23-35. http://revues.cirad.fr/index.php/BFT/article/view/20166

United Nations, 2017. UNdata, Guatemala World Statistics Pocketbook | United Nations Statistics Division. United Nations. http:// data.un.org/en/iso/gt.html

United Nations, 2018. Case study Guatemala: The combined effect of crises and drought. Knowledge Portal Spacebased Information for Disaster Management and Emergency Response. http://www.un-spider.org/projects/rivaf/ case-study-guatemala-combined-effect-crises-and-drought

Bois et Forêts des Tropiques - Revue scientifique du Cirad

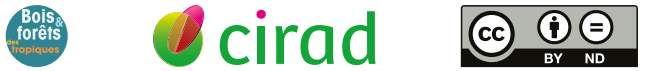

Cirad - Campus international de Baillarguet, 34398 Montpellier Cedex 5, France - Contact: bft@cirad.fr - ISSN: L-0006-579X 